\title{
Pregnancy and childbirth during the coronavirus pandemic. The cross-sectional study of 1321 participants in Poland
}

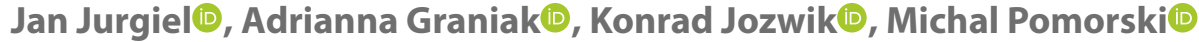 \\ $2^{\text {nd }}$ Department and Clinic of Gynaecology, Obstetrics and Neonatology, Wroclaw Medical University, Wroclaw, Poland
}

\begin{abstract}
Objectives: The impact of infection with novel coronavirus - SARS-CoV-2 - on women's and fetus' was unclear; therefore, it was the reason for many worries. We wanted to understand and describe the worries of pregnant women, assess mental well-being, and analyse the problems affecting prenatal care and hospital stay in this unprecedented time.

Material and methods: We designed an original 23-question survey aimed at women who were pregnant during the pandemic or who gave birth at that time. The survey included demographic data, questions about prenatal care, mental status and worries, and hospitalisation.

Results: Our study included 1321 women: 1010 (76.5\%) during pregnancy and 311 (23.5\%) after the delivery in the studied time. For $1168(88,4 \%)$ respondents, the pandemic had a negative impact on their mood. The three main concerns were: the need for isolation from the child $(n=498,37.7 \%)$, the childbirth without a partner/trusted companion $(n=417,31.6 \%)$ and the risk of infection of the child in hospital $(n=381,28.8 \%)$.

Conclusions: The novel coronavirus pandemic affects the mental health of pregnant women. Pregnant patients should be considered a group of particular concerns. Patients consider remote obstetrical consultations as an insufficient approach. The reason for the highest worries of pregnant patients is a lack of companionship during labour. There was no difference between the rate of childbirth via caesarean sections over vaginal delivery during the "first wave" of the pandemic.
\end{abstract}

Key words: COVID-19; pregnancy; obstetric care; mental health

Ginekologia Polska 2022; 93, 10: 842-846

\section{INTRODUCTION}

In November 2019, the first cases of COVID-19 appeared in Wuhan, China, which was the beginning of the coronavirus pandemic [1]. The impact of infection with novel coronavirus - SARS-CoV-2 - on women's and fetus' well-being was unclear. Chineses experts published the first consensus concerning the topic of perinatal and neonatal management [2]. Nonetheless, the publication had limitations due to insufficient data from infected pregnant patients with COVID-19. Chen et al. reported nine patients with confirmed SARS-CoV-2 infection during pregnancy [3]. None of the patients developed a severe case and most suffered from mild symptoms similar to non-pregnant adults. Due to the small sample of patients, no conclusive data addressed the question of vertical transmission, the risk for the foe- tus and neonate and post-partum course of infection in mothers. That knowledge would have been essential for establishing an adequate approach for the treatment and management of patients. Facing the unknown, many hospitals had to adjust their functioning to the new situation. In Poland, the Ministry of Health announced the first case of COVID-19 on the $4^{\text {th }}$ of March 2020 [4]. After sixteen days of continuous increase in cases, Polish authorities declared a state of an epidemic [5]. Polish Society of Gynaecologists and Obstetricians on $20^{\text {th }}$ of March issued first recommendations concerning patients' triage on the hospital admission. Further recommendations addressed the path of proceedings in obstetrical care and family-attended childbirths [6]. The authors advised reducing unnecessary visits, telemedicine implementation, strict following epidemiological re- 
strictions, and cessation of family-attended births. Pregnant women around the world declared their worries related to the current epidemiological situation. Hence, we wanted to understand and describe their problems in this unprecedented time.

\section{Objectives}

The research's primary objective was to assess how much the pandemic affects responders mental well-being, identify pregnancy-related worries regarding Poland's pandemic, and analyse the problems affecting prenatal care and hospital stay.

\section{MATERIAL AND METHODS}

We designed an original 23-question survey and distributed it via Facebook's groups for pregnant women from the 3 rd of March to the $1^{\text {st }}$ of May. Respondents could participate in the survey if they were pregnant during the study or/and gave birth in that period. The study's participation was voluntary; the participants were informed about the study's aim, and their data were kept in secure storage. A link to the questionnaire was posted on Facebook groups, after the moderators' acceptance, through the account of one of the authors (A.G.). The survey was initiated with demographic items regarding age, education, place of residence, and obstetrical history. Other questions aimed at prenatal care, mental status and worries, and hospitalisation. The questions concerning the worries of responders used a 5-point Likert scale where 1 means "I am not worried" and 5 - "I am terrified".

JASP (Version 0.14.1) and Microsoft Excel was used for statistical analysis. Data were presented as numbers, percentages, mean, and standard deviation. The binomial test was used to determine the change in vaginal versus caesarean section delivery during the pandemic compared to national data.

\section{RESULTS}

Our study included 1321 women: 1010 (76.5\%) during pregnancy and 311 (23.5\%) after the delivery in the studied time. The median age of respondents was 28 (SD 5; range 17 to 49 years). The sociodemographic characteristics of the study population are described in Table 1.

For $1168(88,4 \%)$ respondents, the pandemic had a negative impact on their mood. The majority of women $(n=1049$; 79.4\%) were worried about the pregnancy and delivery during the pandemic. The three main concerns were: the need for isolation from the child ( $n=498,37.7 \%)$, the childbirth without a partner/trusted companion ( $n=417,31.6 \%)$ and the risk of infection of the child in hospital ( $n=381$, $28.8 \%$ ). The concerns which women indicated as the least significant were increased risk of infection or more severe

\begin{tabular}{|l|c|}
\hline \multicolumn{2}{|c|}{ Table 1. The general characteristics of survey respondents } \\
\hline Characteristic & Respondents \\
\hline Age [years] (Mean \pm SD) & $28 \pm 5$ \\
\hline Place of residence [\%] & \\
\hline rural areas & 33 \\
\hline city $<$ 100 k inhabitants & 31 \\
\hline city $<250$ k inhabitants & 12 \\
\hline city $>250$ k inhabitants & 24 \\
\hline Education [\%] & \\
\hline primary and vocational & 9 \\
\hline secondary & 43 \\
\hline university/college & 48 \\
\hline Gravida [\%] & \\
\hline 0 & 1 \\
\hline 1 & 54 \\
\hline 2 & 28 \\
\hline$>2$ & 17 \\
\hline Parity [\%] & 13 \\
\hline 0 & 46 \\
\hline 1 & 34 \\
\hline 2 & 14 \\
\hline$>2$ & 6 \\
\hline Gestational age (week) [\%] & 3 \\
\hline $1-12$ & 10 \\
\hline $12-16$ & \\
\hline $16-20$ & \\
\hline $20-24$ & \\
\hline $24-28$ & \\
\hline $32-36$ & \\
\hline 40 & \\
\hline
\end{tabular}

course because of pregnancy ( $n=124,9,4 \%$ ), the discharge from the hospital too soon $(n=153,11.6 \%)$ and no access to prenatal tests ( $n=160,12.1 \%$ ). The specific data of the main concerns are presented in Table 2.

Due to the pandemic, 355 (26.9\%) patients had to cancel or postpone perinatal tests. The cancellation of a visit with a gynaecologist occurred for 393 (29.8\%) of respondents. In total, 350 women (26.5\%) used an online visit or phone consultation with a gynaecologist, and 15 (1.1\%) of them consider an online visit as "sufficient" care during pregnancy.

In the group of women who gave birth in hospital ( $n=309), 20$ women $(6.5 \%)$ could have a companion, and 10 of them could be visited by the partner after the delivery. The rate of caesarean sections was 130 (42.0\%). After the childbirth, two patients (1\%) were discharged in 24 hours, 


\begin{tabular}{|c|c|c|c|c|c|}
\hline $\begin{array}{l}\text { Answers } \\
\text { Concern }\end{array}$ & $\begin{array}{l}\text { I am not } \\
\text { worried }\end{array}$ & $\begin{array}{l}\text { I am a bit } \\
\text { worried }\end{array}$ & $\begin{array}{l}\text { I am } \\
\text { worried }\end{array}$ & $\begin{array}{c}\text { Iam } \\
\text { apprehensive }\end{array}$ & $\begin{array}{l}\text { Iam } \\
\text { terrified }\end{array}$ \\
\hline $\begin{array}{l}\text { Increased risk of infection or more severe course because } \\
\text { of pregnancy }\end{array}$ & $\begin{array}{c}329 \\
(25 \%)\end{array}$ & $\begin{array}{c}493 \\
(\mathbf{3 7} \%)\end{array}$ & $\begin{array}{c}375 \\
(\mathbf{2 8} \%)\end{array}$ & $\begin{array}{l}85 \\
(6 \%)\end{array}$ & $\begin{array}{c}39 \\
(3 \%)\end{array}$ \\
\hline In case of my infection, I could infect my child & $\begin{array}{c}206 \\
(26 \%)\end{array}$ & $\begin{array}{c}347 \\
(36 \%)\end{array}$ & $\begin{array}{c}501 \\
(38 \%)\end{array}$ & $\begin{array}{c}157 \\
(12 \%)\end{array}$ & $\begin{array}{c}110 \\
(8 \%)\end{array}$ \\
\hline No access to the gynaecologist & $\begin{array}{c}562 \\
(43 \%)\end{array}$ & $\begin{array}{c}258 \\
(20 \%)\end{array}$ & $\begin{array}{c}325 \\
(\mathbf{2 5} \%)\end{array}$ & $\begin{array}{c}103 \\
(8 \%)\end{array}$ & $\begin{array}{l}73 \\
(6 \%)\end{array}$ \\
\hline No access to prenatal tests (ultrasound, blood tests) & $\begin{array}{c}642 \\
(49 \%)\end{array}$ & $\begin{array}{c}220 \\
(17 \%)\end{array}$ & $\begin{array}{c}299 \\
(23 \%)\end{array}$ & $\begin{array}{l}88 \\
(7 \%)\end{array}$ & $\begin{array}{l}72 \\
(5 \%)\end{array}$ \\
\hline Miscarriage/premature delivery due to infection & $\begin{array}{c}480 \\
(36 \%)\end{array}$ & $\begin{array}{c}320 \\
(24 \%)\end{array}$ & $\begin{array}{c}312 \\
(24 \%)\end{array}$ & $\begin{array}{c}108 \\
(\mathbf{8} \%)\end{array}$ & $\begin{array}{c}101 \\
(8 \%)\end{array}$ \\
\hline No place in the hospital or hospital closure & $\begin{array}{c}202 \\
(15 \%)\end{array}$ & $\begin{array}{c}274 \\
(21 \%)\end{array}$ & $\begin{array}{c}490 \\
(\mathbf{3 7} \%)\end{array}$ & $\begin{array}{c}164 \\
(12 \%)\end{array}$ & $\begin{array}{c}191 \\
(\mathbf{1 4 \% )}\end{array}$ \\
\hline No personal protective equipment is available in the hospital & $\begin{array}{c}310 \\
(23 \%)\end{array}$ & $\begin{array}{c}329 \\
(25 \%)\end{array}$ & $\begin{array}{c}425 \\
\mathbf{( 3 2 \% )}\end{array}$ & $\begin{array}{c}146 \\
(11 \%)\end{array}$ & $\begin{array}{c}111 \\
(8 \%)\end{array}$ \\
\hline I will be infected in the hospital & $\begin{array}{c}145 \\
(11 \%)\end{array}$ & $\begin{array}{c}296 \\
(22 \%)\end{array}$ & $\begin{array}{c}550 \\
(42 \%)\end{array}$ & $\begin{array}{c}162 \\
(\mathbf{1 2} \%)\end{array}$ & $\begin{array}{c}168 \\
(13 \%)\end{array}$ \\
\hline Infection of my child in hospital & $\begin{array}{c}128 \\
(\mathbf{1 0 \%})\end{array}$ & $\begin{array}{c}245 \\
(19 \%)\end{array}$ & $\begin{array}{c}567 \\
(43 \%)\end{array}$ & $\begin{array}{c}160 \\
(12 \%)\end{array}$ & $\begin{array}{c}221 \\
(\mathbf{1 7 \%})\end{array}$ \\
\hline Childbirth without a partner/trusted companion & $\begin{array}{c}179 \\
(14 \%)\end{array}$ & $\begin{array}{c}178 \\
(13 \%)\end{array}$ & $\begin{array}{c}547 \\
(41 \%)\end{array}$ & $\begin{array}{c}130 \\
(10 \%)\end{array}$ & $\begin{array}{c}287 \\
(22 \%)\end{array}$ \\
\hline I will be forced to deliver by caesarean section & $\begin{array}{c}516 \\
(39 \%)\end{array}$ & $\begin{array}{c}260 \\
(20 \%)\end{array}$ & $\begin{array}{c}312 \\
(\mathbf{2 4 \%} \%)\end{array}$ & $\begin{array}{c}96 \\
(7 \%)\end{array}$ & $\begin{array}{c}137 \\
(\mathbf{1 0 \%})\end{array}$ \\
\hline Lack of medical personnel during delivery & $\begin{array}{c}218 \\
(7 \%)\end{array}$ & $\begin{array}{c}307 \\
(23 \%)\end{array}$ & $\begin{array}{c}456 \\
(35 \%)\end{array}$ & $\begin{array}{c}162 \\
(12 \%)\end{array}$ & $\begin{array}{c}178 \\
(13 \%)\end{array}$ \\
\hline No access to anaesthesia & $\begin{array}{c}423 \\
(32 \%)\end{array}$ & $\begin{array}{c}288 \\
(22 \%)\end{array}$ & $\begin{array}{c}361 \\
(27 \%)\end{array}$ & $\begin{array}{c}116 \\
(9 \%)\end{array}$ & $\begin{array}{c}133 \\
(\mathbf{1 0 \%})\end{array}$ \\
\hline Need of isolation from my child & $\begin{array}{c}83 \\
(6 \%)\end{array}$ & $\begin{array}{c}175 \\
(13 \%)\end{array}$ & $\begin{array}{c}565 \\
(43 \%)\end{array}$ & $\begin{array}{c}158 \\
(12 \%)\end{array}$ & $\begin{array}{c}340 \\
(26 \%)\end{array}$ \\
\hline I won't be able to breastfeed due to the epidemic situation & $\begin{array}{c}266 \\
(20 \%)\end{array}$ & $\begin{array}{c}249 \\
(19 \%)\end{array}$ & $\begin{array}{c}452 \\
\text { (34\%) }\end{array}$ & $\begin{array}{c}142 \\
(11 \%)\end{array}$ & $\begin{array}{c}212 \\
(\mathbf{1 6 \% )}\end{array}$ \\
\hline I will be discharged from the hospital too soon & $\begin{array}{c}604 \\
(46 \%)\end{array}$ & $\begin{array}{c}287 \\
(22 \%)\end{array}$ & $\begin{array}{c}277 \\
(21 \%)\end{array}$ & $\begin{array}{c}84 \\
(6 \%)\end{array}$ & $\begin{array}{c}69 \\
\mathbf{( 5 \% )}\end{array}$ \\
\hline
\end{tabular}

\section{Table 3. Obstetrical care during the "first wave" of COVID-19 pandemic}

\begin{tabular}{|c|c|c|}
\hline $\begin{array}{l}\text { Answers } \\
\text { Questions }\end{array}$ & Yes & No \\
\hline Did the epidemic make you cancel a visit with your gynaecologist? & $\begin{array}{c}393 \\
(30 \%)\end{array}$ & $\begin{array}{c}805 \\
(61 \%)\end{array}$ \\
\hline Due to the epidemic situation in the country, did you have to give up on scheduled prenatal tests? & $\begin{array}{c}355 \\
(27 \%)\end{array}$ & $\begin{array}{c}966 \\
(73 \%)\end{array}$ \\
\hline Did you use an online visit/phone consultation with your gynaecologist? & $\begin{array}{c}350 \\
(26 \%)\end{array}$ & $\begin{array}{c}945 \\
(72 \%)\end{array}$ \\
\hline Do you think that an online visit is "sufficient" care during pregnancy? & $\begin{array}{c}15 \\
(1 \%)\end{array}$ & $\begin{array}{c}1253 \\
(95 \%)\end{array}$ \\
\hline Did you have to change your gynaecologist because of the epidemic in your country? & $\begin{array}{c}192 \\
(15 \%)\end{array}$ & $\begin{array}{c}1129 \\
(85 \%)\end{array}$ \\
\hline
\end{tabular}

85 patients ( $27 \%$ ) in 48 hours, 114 patients ( $37 \%$ ) in 72 hours, 42 patients (14\%) after four days, and 66 patients (21\%) after five days of hospitalisation.
In the group of hospitalised patients, $28 \%$ felt that they were not adequately protected against SARS-COV- 2 infection during hospitalisation. One-third of the hospitalised 
patients believed that not all medical professionals took precautions in the form of protective masks and gloves.

\section{DISCUSSION}

The COVID-19 pandemic is an unprecedented time for a modern healthcare system around the globe. In this time, the safety of patients and appropriate medical care remains of the highest importance. Since the beginning of the global pandemic, scientists made giant strides in the battle against SARS-COV-2 - they created, tested, and produced effective vaccines. With this remarkable invention, people could have almost been back to their pre-pandemic life. However, the thread of the novel coronavirus did not disappear - results of national vaccination strategies are far from the safe threshold of herd immunity. SARS-COV-2, with its frequent mutations, persist in a significant problem for public health, especially considering the possible variants, which can have higher transmissibility and escape from the immunity obtained with vaccinations. In this scenario, lessons learnt from the "first wave" of the global pandemic remains essential for the future.

\section{Impact on the mental health}

In this online survey of 1321 responders, we found that the worries related to pregnancy during the pandemic are important issues affecting responders psychological well-being. Most of the respondents declared that they observed a decrease in their mood. Sun and al. and Yan et al. conducted studies assessing the mental status of pregnant women $[7,8]$. In those systemic reviews, authors found a higher prevalence of mental problems, anxiety and depression in women during and after pregnancy during coronavirus pandemic. According to Glover et al., children of mothers who suffered from anxiety and/or depression are more likely to develop a range of adverse neurodevelopment outcomes [9]. Thereby, the impact of mental status is of paramount importance considering long-term effects on offspring. Thus, pregnant patients should be considered "a group of special care" in the sense of psychological support and long term outcomes for mother and child. The obstetrician's role is crucial to understand the worries of patients and ensure proper care during pregnancy.

\section{Prenatal care}

We wanted to establish the questionnaire's issues during prenatal care and fears related to the hospital stay. For almost a third of responders, obstetrical visits were cancelled due to the pandemic situation. It might have been related to the advised limitations in the number of visits, which did not put patients at risk of infection during their visit. In only $9 \%$ of cases, patients participated in the telemedicine check-up instead of the traditional visit. Patients declare that remote communication is not sufficient and cannot replace traditional visits. Those opinions may explain attitude towards remote medical consultations and their occasional use in this group. Similarly, perinatal testing was postponed or cancelled in almost a third of patients due to the pandemic.

In our opinion, communication via phone or computer is essential when the increased risk of infections exists. The approach advised in the Polish Society of Gynaecologists and Obstetricians' recommendation suggested that certain visits and tests could be postponed without putting the patient at risk. These situations should be considered as a separately balancing of patients' advantages and disadvantages of the decision. Nevertheless, in each situation, the patients should be informed what the reason behind the cancellation or postponement was. Appropriate contact could improve the sense of security and the relationship between the patient and the obstetrician.

\section{Worries}

During "the first wave" of coronavirus pandemic, many hospitals decided to cease the accompanied births to stop the virus's possible spread into the wards. Those actions were needed in the situation of the novel virus without established testing and treating management. The lack of companionship was considered a factor of the highest rate of concerns in the study for pregnant patients, affecting their mental well-being. Thus, many patients and their families criticised those strict measures of prevention. In contrast, respondents expressed relatively rare concerns about the limited access to prenatal tests, to a gynaecologist, and too early discharge. In our opinion, it is crucial to provide the appropriate environment for the pregnant with the support of close ones, but this objective could not be achieved without putting the other patients and medical staff in danger. In many cases, the cessation of the accompanied births was the only opportunity to prevent a burgeoning number of infections. Currently, vaccination of pregnant women, their family, birth companions should be advised during the obstetrical visits - thus, establishing the safety of the pregnant, a child, and medical personnel.

\section{Hospitalisation and labour}

Initially, some experts opted for the elective caesarean section for all patients with confirmed SARS-CoV-2 infection to prevent vertical transmission. Similarly, mothers in several countries expressed their will to have a caesarean section during the COVID-19 pandemic, finding it safer for child birthing. In their systemic review, Cai et al. found no superiority of the caesarean section compared to vaginal delivery in protecting against vertical transmission and neonatal and maternal death rates [10]. The objective of our study was to assess if the pandemic affected the caesar- 
ean section in the country compared to previous years. According to the Health Ministry data from 2018, Poland has a high rate of caesarean sections - $43,85 \%$. Our result of $42 \%$ suggests that the current epidemiological situation did not affect decision-making and qualification to this procedure. The vast majority of patients was discharged early in 48 to 72 hours after the delivery. This approach might be considered as the shortening of hospitalisation and minimalising the chance of intrahospital infection.

The fact that many patients did not feel well protected against infection of SARS-CoV-2 in hospital can lead to questioning health care workers authority. In times of growing anti-vaccine attitudes, it is crucial that medical staff take basic measures to protect themselves and their patients from infection.

\section{Strengths}

Our study's strength is the number of participants with a relatively similar age and demographic characteristics distribution. To our knowledge, it is the largest Polish study focused on the mental health and hospitalisation of the pregnant and post-partum participants during the pandemic yet to be performed.

\section{Limitations}

This study has a potential limitation. The survey was posted and filled out by the member of social media groups. Therefore, the study sample could have been biased by the auto-selection of the responders.

\section{CONCLUSIONS}

1. The novel coronavirus pandemic affects the mental health of pregnant women. Pregnant patients should be considered a group of particular concerns.

2. Patients consider remote obstetrical consultations as an insufficient approach.

3. The reason for the highest worries of pregnant patients is a lack of companionship during labour. It can be resolved with the higher vaccination of society.

4. There was no difference between the rate of childbirth via caesarean sections over vaginal delivery during the first wave of the pandemic.
5. Further research should be conducted to assess the maternal health problems of pregnant women and establish a suitable approach.

\section{Acknowledgements}

We thank Mr Daniel Kazarnowicz for the help in the data analysis in this article.

\section{Conflict of interest}

All authors declare no conflict of interest.

\section{REFERENCES}

1. Huang C, Wang Y, Li X, et al. Clinical features of patients infected with 2019 novel coronavirus in Wuhan, China. Lancet. 2020; 395(10223): 497-506, doi: 10.1016/S0140-6736(20)30183-5, indexed in Pubmed: 31986264.

2. Wang $L$, Shi $Y$, Xiao T, et al. Working Committee on Perinatal and Neonatal Management for the Prevention and Control of the 2019 Novel Coronavirus Infection. Chinese expert consensus on the perinatal and neonatal management for the prevention and control of the 2019 novel coronavirus infection (First edition). Ann Transl Med. 2020; 8(3): 47, doi: 10.21037/atm.2020.02.20, indexed in Pubmed: 32154287.

3. Chen $\mathrm{H}$, Guo J, Wang $\mathrm{C}$, et al. Clinical characteristics and intrauterine vertical transmission potential of COVID-19 infection in nine pregnant women: a retrospective review of medical records. Lancet. 2020; 395(10226): 809-815, doi: 10.1016/S0140-6736(20)30360-3, indexed in Pubmed: 32151335.

4. Pierwszy przypadek koronawirusa w Polsce - Ministerstwo Zdrowia - Portal Gov.pl [Polish]. Ministerstwo Zdrowia n.d. https://www.gov.pl/web/zdrowie/pierwszy-przypadek-koronawirusa-w-polsce (January 4, 2021).

5. Rozporzadzenie Ministra Zdrowia z dnia 20 marca 2020 r. w sprawie ogłoszenia na obszarze Rzeczypospolitej Polskiej stanu epidemii Polska w RPA - Portal Gov.pl \{Polish]. Polska w RPA n.d. https://www. gov.pl/web/rpa/rozporzadzenie-ministra-zdrowia-z-dnia-20-marca-2020-r-w-sprawie-ogloszenia-na-obszarze-rzeczypospolitej-polskiej-stanu-epidemii (January 4, 2021).

6. Rekomendowana ścieżka postępowania dla kobiet w ciąży COVID-19 | PTGiP n.d. https://www.ptgin.pl/rekomendowana-sciezka-postepowania-dla-kobiet-w-ciazy-covid-19 (January 3, 2021).

7. Sun F, Zhu J, Tao H, et al. A systematic review involving 11,187 participants evaluating the impact of COVID-19 on anxiety and depression in pregnant women. J Psychosom Obstet Gynaecol. 2021; 42(2): 91-99, doi: 10.1080/0167482X.2020.1857360, indexed in Pubmed: 33327827.

8. Yan H, Ding Y, GuoW. Mental health of pregnant and postpartum women during the coronavirus disease 2019 pandemic: A systematic review and meta-analysis. Front Psychol. 2020; 11: 617001, doi: 10.3389/fpsyg.2020.617001, indexed in Pubmed: 33324308.

9. Glover V. Maternal depression, anxiety and stress during pregnancy and child outcome; what needs to be done. Best Pract Res Clin Obstet Gynaecol. 2014; 28(1): 25-35, doi: 10.1016/j.bpobgyn.2013.08.017, indexed in Pubmed: 24090740.

10. Cai J, Tang Mi, Gao Yu, et al. Cesarean section or vaginal delivery to prevent possible vertical transmission from a pregnant mother confirmed with COVID-19 to a neonate: A systematic review. Front Med (Lausanne). 2021; 8: 634949, doi: 10.3389/fmed.2021.634949, indexed in Pubmed: 33681259. 